\title{
NECTIN4 wt Allele
}

National Cancer Institute

\section{Source}

National Cancer Institute. NECTIN4 wt Allele. NCI Thesaurus. Code C134480.

Human NECT IN4 wild-type allele is located in the vicinity of $1 \mathrm{q} 23.3$ and is approximately $19 \mathrm{~kb}$ in length. This allele, which encodes nectin- 4 protein, plays a role in cell-cell adhesion. Mutation of the gene is associated with ectodermal dysplasia-syndactyly syndrome 1. 